\title{
Entre ler, traduzir e comunicar: entrevista com Bruno Fiuza
}

Entrevista por Matheus de Paula Silva e Pedro José de Carvalho Neto

Transcrição por Marina de Almeida Spinola

Revisão por Matheus de Paula Silva, Pedro José de Carvalho Neto e Yan Fernando Pereira Catuaba

DOI: 10.11606/issn.2318-8855.v9i2p15-37 


\section{entrevista}

Entre ler, traduzir e comunicar

Como um "acaso", descreve Bruno Fiuza, a escolha de ingressar no curso de História da USP em 2002. Um músico e ator amador, interessado em cultura e artes, optou antes pelo curso de Jornalismo na PUC-SP, pois achava a carreira artística muito arriscada. Pelo fato de não conseguir manter ao mesmo tempo, trabalho, curso de Jornalismo e História, decidiu por abandonar o último, reingressando somente em 2006.

Como o leitor e leitora poderá perceber, foi na confluência dessas duas áreas que Bruno se encontrou na carreira como editor. Em tom franco, ele nos conta sobre duas experiências bem distintas na área: uma na revista de divulgação História Viva e outra na tradicional editora científica Springer. Permanece nessa transição aquilo que aprendeu de mais importante no Departamento de História: a leitura crítica de um texto. Aos estudantes interessados no ofício, Bruno diz que é necessário flexibilidade e conhecimentos específicos, mas faz questão de destacar que as coisas nem sempre acontecem como planejamos.

Boa leitura a todas e a todos!

Revista Epígrafe: Como foi sua aproximação com a História e o que o levou a fazer o curso?

Bruno Fiuza: Quando eu estava terminando o ensino médio, eu, como muita gente, não sabia muito bem o que fazer da vida, e gostava muito de cultura, artes, etc. Era músico amador, ator amador, mas eu achava que seguir esse caminho era muito arriscado, então, eu sempre gostei muito de ler e escrever, aquela coisa meio básica, aí eu falei: "Bom, acho que eu vou de Jornalismo", porque o meu plano era trabalhar com jornalismo cultural. Então eu achei que trabalhando com jornalismo cultural, eu iria acabar trabalhando com música, artes, essas coisas que eu gostava; e, naquela 


\section{entrevista}

Bruno Fiuza

época, eu achava que eu estudando jornalismo eu teria uma profissão que me permitiria me sustentar. Hoje, olhando para trás, vejo que foi um enorme erro, mas naquela época eu achava isso de fato [risos]. E foi assim, eu terminei o ensino médio e aí eu prestei o vestibular para Jornalismo, prestei para a USP [Universidade de São Paulo] e para a PUC [Pontifícia Universidade Católica]. Eu não passei na USP, passei na PUC e comecei a fazer Jornalismo na PUC. E o meu plano era estudar jornalismo e ser jornalista, mas, quando eu comecei o curso, eu fiquei muito decepcionado, achei fraco. Hoje, olhando para trás, eu percebo que, na verdade, eu achei o curso fraco por conta de um problema intrínseco no Jornalismo: ele é uma prática, não um campo de conhecimento. Então, talvez, acho que esperava entrar na faculdade e aprender um monte de coisa, mas você fica muito perdido no começo.

Aí acabei resolvendo cursar História, é uma história engraçada, porque tem muito acaso. Se eu falar para vocês que "nossa, foi um plano", não. Na verdade, nessa época, eu estava no primeiro ano de Jornalismo, e um dos meus melhores amigos do colégio queria prestar Letras na USP, e, nessa época, eu morava perto da USP, a casa da minha mãe é perto do Portão 1. Aí ele: "Ah, você pode fazer minha inscrição na FUVEST [Fundação Universitária para o Vestibular]?". E eu: "Posso", porque era do lado. Um dia fui andando para a FUVEST, fazer a inscrição dele, e estava infeliz com o curso de Jornalismo e pensei "eu moro do lado, por que eu não tento fazer alguma coisa aqui na USP também?". Mas... O que? E aí eu comecei a pensar as coisas que eu gostava na escola, tipo, sempre gostei muito de História, de Geografia, eu me interessava por Ciências Sociais, Economia, Psicologia, ou seja, um bando de coisas. Falei: “No colégio, História sempre foi minha matéria favorita, vou prestar História”, mas eu nunca prestei História pensando em ser historiador. Na época, eu pensei a História como uma forma de complementar minha formação jornalística - e é muito irônico porque, hoje, a formação histórica é muito mais importante que a de jornalista. Aí, eu 


\section{entrevista}

Entre ler, traduzir e comunicar

cursei por um ano as duas juntas, mas assim, eu já estava no segundo ano de Jornalismo e pensei o que eu iria fazer, porque precisava começar a trabalhar e eu não iria conseguir fazer isso, mais duas graduações ao mesmo tempo. Então eu tranquei a USP por três anos e só voltei para a História depois que eu terminei o Jornalismo.

Revista Epígrafe: Quando?

Bruno Fiuza: Eu voltei no segundo semestre de 2006. Cursei 2002 inteiro, aí fiquei trancado em 2003, 2004 e 2005, voltei em 2006. Nisso, eu já estava formado no Jornalismo. E aí eu fiz uma pós na Espanha e quando voltei um amigo meu me convidou para editar uma edição da revista História Viva, já que eu disse que estava retornando para a área de História. A minha retomada da graduação de História esteve intimamente ligada ao meu trabalho na História Viva. Eu comecei a trabalhar na revista como freelancer no fim de 2006. Em maio de 2007, eu fui contratado como editor assistente, e em 2009, se não me engano, tornei-me editor da revista e segui no cargo até 2012. Durante esse período, eu estava na graduação na USP, o que foi uma sinergia fantástica, porque eu era editor lá e eu tive a sorte de ter o contato com os professores do Departamento, criei parcerias super legais com vários, que colaboraram com a revista. A Marlene [Suano] foi uma que escreveu bastante; o [Osvaldo] Coggiola, eu brinco com ele que deviam fazer uma estátua para ele na Editora, porque o que ele publicou na História Viva é uma grandeza; mas não só eles, um monte de gente do Departamento, Marlene, Coggiola, Elias [Tomé Saliba], Marcelo Cândido, Ângelo Segrillo, Sean Purdy, um monte de gente escreveu, então isso foi muito legal.

Eu concluí a graduação em 2011 e fiquei mais um ano só trabalhando na revista. Em 2012, fui demitido porque a empresa quis mudar a redação para o Rio de Janeiro e eu não quis ir. Eu estava vendo que o mercado de trabalho para Jornalismo 


\section{entrevista}

Bruno Fiuza

estava muito ruim, eu pensei "bom, acho que eu vou precisar de uma transição de carreira", porque eu não via mais futuro naquela área. Eu gostava de pesquisa, mas nunca tinha desenvolvido um projeto mesmo. Aí, quando eu estava saindo da revista, eu entrei em contato com todos os colaboradores que tive nessa época e falei que estava saindo. Assim, o Coggiola perguntou o que eu estava pensando em fazer e eu disse que talvez tentaria um mestrado no Departamento de História, ele disse que se eu tivesse algum projeto, ele teria o maior prazer de orientar. Eu prestei a prova do mestrado e comecei em 2013, na USP, com o Coggiola. Eu fiz o mestrado, que demorou muito tempo e eu tive que pedir prorrogação, entreguei minha dissertação em 2016, defendi no ano seguinte e, assim, minha relação com o Departamento terminou oficialmente em março de 2017, o que significa basicamente que, entre idas e vindas, eu passei quase quinze anos na USP.

Nesse meio tempo, houve uma mudança na minha vida profissional também, porque eu não tinha condições de fazer o mestrado com bolsa, eu já era mais velho e tinha uma série de gastos, então eu fiz o mestrado trabalhando. Logo depois de ser demitido da revista, eu fui convidado para trabalhar em uma agência de criação de conteúdo com comunicação corporativa, que é um negócio que eu detestava. TrabaIhei por três anos ainda com comunicação, na parte mais próxima do jornalismo. Em 2015, uma pessoa que trabalhou comigo na mesma editora que publicava a História Viva foi parar na editora Springer e, pelo LinkedIn, ela divulgou que tinha aberto uma vaga de editor de Ciências Sociais. Me candidatei a essa vaga e fui contratado.

Revista Epígrafe: Isso em que ano?

Bruno Fiuza: 2015. Eu comecei a trabalhar na Springer em outubro de 2015. E foi aí que eu digo que eu completei minha transição de carreira. Eu abandonei a carreira de 


\section{entrevista}

Entre ler, traduzir e comunicar

jornalismo e hoje eu me dedico puramente à publicação científica. Então, hoje, quando as pessoas perguntam minha profissão, eu nem respondo que sou jornalista, e sim que eu sou editor de livros. Mas, para chegar onde eu estou hoje, meu trabalho na História Viva foi fundamental, e a minha experiência lá esteve intimamente ligada com minha vivência aqui no Departamento de História. Então, bem resumidamente, esse é o percurso, mas como vocês podem ver, está um percurso longe de ser fruto de um planejamento.

Revista Epígrafe: Em relação à sua formação, você falou que teve contato com vários professores. Quais marcaram a sua passagem? Quem você colocaria como professores que te marcaram?

Bruno Fiuza: Alguns me marcaram muito. Acho que o professor mais incrível que eu tive aqui no Departamento de História foi o István Jancsó. Eu tive aula com ele no meu primeiro ano. Assim, o István me ensinou a ter uma visão sistêmica de qualquer coisa que você estuda, sabe? Acho que, primeiro, ter tido aula com o István foi um privilégio, um pesquisador histórico e tal; mas, para mim, o István foi o professor que tive aqui no Departamento de História que melhor ensinou o que é ser um pesquisador, sabe? Inclusive, na disciplina dele, ele pedia para gente fazer um projeto de pesquisa. A Laura de Mello e Souza também foi uma professora que me marcou muito, uma professora incrível também, que deu uma ideia do que é um projeto de pesquisa. E a Laura é fantástica. Bom, o Coggiola, porque eu acho o Coggiola um excelente professor e fui orientando dele, fiz um ótimo relacionamento profissional. A Marlene, porque a disciplina que eu fiz com ela foi um semestre em que ela ensinava para gente metodologia de pesquisa. O Jorge Grespan, eu lembro que a aula do Jorge foi um negócio incrível, eu aprendi a ler Marx com o Jorge, então, pô, demais. Quem mais? 0 


\section{entrevista}

Bruno Fiuza

Sean Purdy foi um dos primeiros professores que eu tive quando eu voltei, fora que o Sean é uma pessoa simpaticíssima e também foi uma das primeiras pessoas que começou a colaborar com a História Viva; uma coisa que eu acho que é uma contribuição muito legal do Sean para o departamento é que aqui tem um nível de francofilia muito alto, tipo, era história francesa. Então, eu acho que a contribuição que o Sean trouxe da historiografia britânica me marcou bastante também. Quem mais? Tem um monte de gente como vocês podem ver [risos], mas eu diria, posso estar cometendo alguma injustiça aqui, mas eu diria que esses foram os principais, eu acho.

Revista Epígrafe: Durante a graduação você tinha algum interesse pela área acadêmica ou isso só veio depois? Você sempre teve essa vontade de fazer mestrado?

Bruno Fiuza: Não.

Revista Epígrafe: Foi um negócio que surgiu depois? Qual é a relação sua com a pesquisa acadêmica?

Bruno Fiuza: É, o mestrado foi uma coisa que surgiu depois. Durante a graduação eu não tinha essa perspectiva, esse plano. Na verdade, a coisa toda do mestrado veio por conta de dois caminhos: um deles porque eu estava, digamos, num momento de encruzilhada da minha vida e buscava outro caminho. O outro foi o seguinte: eu passei cinco anos editando textos de pesquisa de pesquisadores, o que é uma coisa que eu acho super legal, mas, assim, eu sentia falta de eu mesmo pesquisar, sabe? Tipo, “legal, eu edito os textos dessas pessoas e eles são incríveis, mas eu queria saber fazer isso daí também, queria aprender a fazer isso aí também" e o mestrado veio um pouco por causa disso. 


\section{entrevista}

Entre ler, traduzir e comunicar

Existe uma história particular do tema do meu mestrado, o porquê da escolha do tema do meu mestrado. O meu mestrado, no fundo, foi uma tentativa de sistematizar uma pesquisa que eu passei, sei lá, uns 15 anos fazendo informalmente, porque no meu mestrado eu estudei uma rede de movimentos sociais da qual eu participei um pouquinho quando eu estava no primeiro ano da graduação de Jornalismo. Aquilo foi uma experiência que me marcou muito pessoalmente. Eu comecei o mestrado com 31 anos, e eu tinha uma coisa na minha cabeça de que eu nunca tinha feito, nunca tinha produzido uma obra. E aí tinha, por outro lado, essa vivência com essa história dessa rede, então eu acho que o mestrado também tem um pouco a ver com essa, digamos, vontade que eu tinha de poder falar "essa coisa é minha, fui eu que fiz, essa é minha obra", sabe? Então foi uma coisa que não foi fruto de um planejamento, e hoje em dia eu até me arrependo. Se eu pudesse voltar no tempo, eu teria percorrido o caminho tradicional, eu teria feito tudo certinho, teria feito uma iniciação científica, essa coisa toda, porque eu acabei fazendo meu mestrado muito velho para os padrões normais. Mas, assim, eu me formei na graduação com 29 anos, eu comecei o mestrado eu tinha 31. E quando terminei o mestrado, prometi para mim mesmo que nunca mais ia fazer um projeto de pesquisa formal estando trabalhando, porque é muito desgastante e hoje eu não consigo fazer um doutorado porque para fazer o doutorado sem trabalhar, eu precisaria da bolsa e a bolsa hoje não cobre os meus gastos. Então, talvez, se eu fosse mais novo, eu poderia ter feito isso de outra forma. Hoje em dia, apesar de eu gostar muito de pesquisar, eu não tenho como fazer um doutorado. Hoje, eu pago pela minha falta de planejamento.

Revista Epígrafe: Então, já entrando na questão do mercado editorial, você, como historiador e como jornalista, o que diria sobre como essas formações te ajudaram na sua prática, no seu dia-a-dia de editor? 


\section{entrevista}

Bruno Fiuza

Bruno Fiuza: O meu percurso é meio caótico, não foi planejado, mas no final das contas essas duas formações ajudaram. Eu acho que as duas formações me deram recursos e habilidades que são complementares. Eu acho que o jornalismo me ajudou pelo seguinte: eu acho que o mercado editorial, ainda que não seja um ramo específico da comunicação, ele não deixa de ser, de certa forma, uma forma de comunicação. No fundo, seja uma revista, seja um periódico científico, um livro, na verdade a gente está falando de meios que permitem com que a pesquisa produzida ou qualquer coisa que foi produzida por alguém possa ser levada para outra pessoa e isso não deixa de ser um processo da comunicação. Então, eu acho que a minha experiência como jornalista me ajudou muito numa coisa que eu acho absolutamente fundamental no mercado editorial que é o estabelecimento, o cultivo e o desenvolvimento de uma rede de relacionamentos. O maior patrimônio de um jornalista são os contatos dele, é a rede de relacionamentos que ele tem. Eu costumo dizer que só tem uma coisa que eu sou, que eu realmente tenho talento, que é ser tradutor. E aí tradutor não é só de línguas, acho que, por exemplo, quando eu trabalhava na História Viva, o que eu fazia era traduzir o conteúdo da pesquisa histórica para um público leigo. Quando, hoje, meu trabalho é traduzir as práticas e os hábitos dos pesquisadores latino-americanos para uma empresa estrangeira ou traduzir a publicação internacional para pesquisadores daqui, eu acho que o jornalismo foi fundamental nisso, porque ele me ensinou a criar, cultivar e desenvolver relacionamentos. $\mathrm{E}$ isso eu acho que foi contribuição do jornalismo.

A contribuição da história é muito mais óbvia, porque eu acho que o jornalismo me ensinou "como", mas a história me ensinou o "o quê", o contexto do conteúdo. A história me ensinou o que é a vida acadêmica, o que é a produção do conhecimento acadêmico. Isso tudo eu aprendi na faculdade de História. Então, digamos que o jor- 


\section{entrevista}

Entre ler, traduzir e comunicar

nalismo me deu as ferramentas, que na psicologia nós chamaríamos de habilidades sociais para trabalhar com pesquisadores. Eu acho que a história me deu o conhecimento necessário para entender o que é o mundo acadêmico. Para além disso, eu acho que tenho uma contribuição que é específica da história - porque eu poderia ter a vivência acadêmica em vários cursos daqui, mas eu acho que tem uma contribuição específica da história: buscar uma visão global e integradora das coisas, é muito isso que eu falo da lição do István, de buscar os mecanismos profundos dos processos, e eu acho que isso é algo que me ajuda na vida, não só no trabalho, mas acho que também na vida.

Revista Epígrafe: Provavelmente um editor precisa ler muito também, saber as críticas dos textos, saber as pequenas habilidades... Como elas contribuíram dentro do mercado editorial?

Bruno Fiuza: Isso foi bem importante mesmo. Eu acho que, não só a familiaridade com os textos, que é, sem dúvida, muito importante, mas também a visão crítica sobre o texto, a capacidade de fazer a análise crítica de um texto, isso que é um aprendizado do curso de História que é fundamental. Se tem uma coisa que a gente aprende aqui é fazer uma leitura crítica de um texto e eu acho que isso para um editor é fundamental.

Eu acho que tem uma outra questão também que o curso de História ensina a entender a história de um texto. Por exemplo, na editora, hoje, eu trabalho como editor de Ciências Humanas e Sociais. Se você vai falar com alguém que trabalha com psicologia experimental, por exemplo, não faz o menor sentido você falar tipo “olha, mas a edição de 1910 tem esse prefácio que essa edição de 1914 não tem". Para eles isso é grego, isso não existe, para eles um texto é um texto e acabou e beleza. A gente 


\section{entrevista}

Bruno Fiuza

tem essa preocupação, sabe? Essa coisa de perceber assim, a história por trás da produção de um texto. Isso é uma coisa que o curso de História nos ensina e que eu acho que para um editor é fundamental, porque, ao contrário de outros cursos, que naturalizam o texto, veem o texto como uma coisa pronta, a gente analisa o texto como o resultado de um processo e eu acho isso muito legal para o editor. Às vezes, quando a gente vê um livro publicado parece que o autor escreveu aquele texto tal qual e com esse trabalho da edição você vê que não, que, na verdade, entre uma pesquisa e uma publicação dessa pesquisa tem um mundo. E eu acho, até que quando você é um estudante de História, você vê isso, porque você entende essa questão que o texto é processo de uma produção, que não caiu do céu.

Revista Epígrafe: Emendando um pouco essa sua resposta, quais você considera que são as competências que um editor precisa ter?

Bruno Fiuza: Eu acho que antes de responder essa pergunta, a gente precisa saber que quando a gente fala editor, às vezes, a gente está falando de coisas diferentes. Existem vários tipos de editor. E eu mesmo já tive duas experiências radicalmente opostas. Por exemplo, quando eu trabalhava na História Viva, eu trabalhava muito com o texto do autor, eu ajudava o autor a dar forma ao texto, isto é, um trabalho de edição. Hoje, eu não mexo no texto dos autores. Antes eu trabalhava com divulgação científica, que por natureza é você pegar a produção científica acadêmica e tornar ela palatável para o público. Então, tem um trabalho aí, esse trabalho de tradução grande. Hoje, eu trabalho com publicação científica stricto sensu, então os livros que eu publico hoje não são para o grande público, eles são para pesquisadores. A minha função hoje é uma coisa que é chamada de editor de aquisição, o meu trabalho hoje é 


\section{entrevista}

Entre ler, traduzir e comunicar

identificar projetos que tenham potencial para serem publicados e ajudar os autores nesse processo. Mas eu não edito mais texto, isso é uma coisa que eu não faço.

Então, o próprio trabalho do editor é diferente dependendo da natureza da publicação com a qual ele trabalha. Por exemplo, acho que uma primeira habilidade fundamental é entender os dois pólos do processo, os dois pólos, digamos, do mundo com o qual você trabalha. Um editor sempre trabalha com um lado que gera o conteúdo e outro que vai consumir esse conteúdo, e esses dois mundos são completamente diferentes, e uma habilidade do editor é saber diferenciar esses dois mundos e entender, por um lado, quem produz esse conteúdo e, por outro, quem vai consumir esse conteúdo.

Eu acho que, bom, tem uma habilidade que é auto evidente que é o bom domínio do texto escrito, eu acho que isso é meio óbvio, mas o editor precisa ser uma pessoa capaz de gerar um bom texto, mesmo se não for trabalhar com isso. Por exemplo, muitas vezes meu trabalho na História Viva era ajudar os autores a deixar o texto mais interessante, mais compreensível para o público.

Existe uma outra habilidade que é essa construção e manutenção do relacionamento, porque o editor é um intermediário. O editor não é um produtor original, ele sempre vai depender de um autor, sem autor não existe editor. Então, essa capacidade de construir e desenvolver relacionamentos é uma habilidade fundamental para o editor, essa capacidade de entender o mundo do outro, porque, essencialmente, o editor sempre vai trabalhar com o mundo do outro. A minha intenção é entender o que meu público quer e tentar casar essas coisas. Não é o que eu quero, eu posso ter minhas preferências pessoais, claro, e certamente minhas escolhas vão ser pautadas pelas minhas preferências pessoais, mas não sou eu que produzo. Na verdade, o editor é um facilitador, eu acho que ele tem que ter essa capacidade. 


\section{entrevista}

Bruno Fiuza

Eu acho que tem um elemento comum ao trabalho de editor, na posição que seja, que é um trabalho de curador. O editor é, acima de tudo, um curador, um filtro, por isso eu acho que é um papel tão relevante para esse momento que a gente vive. Antigamente, a gente tinha uma escassez de conteúdo, para você achar um livro era um parto. Hoje, você tem excesso de conteúdo, se você tem uma dúvida sobre um fato histórico, você entra no Google, você entra na Wikipédia, você entra onde você quiser. Então, eu acho que existe um elemento comum ao trabalho do editor que é um trabalho de curadoria: “O que é um conteúdo relevante para o público com o qual eu trabalho?". Então, um papel importante do editor é ser esse filtro, é, de repente, não deixar publicar um livro que é uma porcaria só porque, enfim, passou. Porque, na verdade, o avanço das tecnologias de informação e comunicação, eles redimensionaram muito o trabalho de quem mexe com essa intermediação entre um conteúdo e o outro. Na verdade, sendo absolutamente sincero, qualquer pessoa que quiser escrever um livro, escreve no Word, cria um PDF e publica na internet. A rigor, no limite, você não precisa mais de um editor, qualquer um pode escrever um livro. Vocês podem até vender pela Amazon se quiserem, não precisa nem de editora, entendeu? Por exemplo, qual a diferença entre um PDF que está num repositório qualquer na internet e um livro publicado pela Springer? É que a Springer é uma editora fundada em 1875, que tem uma tradição gigantesca e as pessoas provavelmente vão olhar e pensar que é confiável. No fundo é isso, entendeu?

Revista Epígrafe: Bom, e como é, no fim das contas, o trabalho cotidiano em editora?

Bruno Fiuza: Bem, a resposta que eu vou dar para essa pergunta é necessariamente parcial, porque eu vou falar das experiências que eu tive, e só essas experiências que eu tive são muito diferentes uma da outra. Por exemplo, na História Viva o meu traba- 


\section{entrevista}

Entre ler, traduzir e comunicar

Iho cotidiano era basicamente um trabalho de mexer com texto, era pegar o texto de um autor e dar uma forma legal para esse texto. Eu diria que quando eu trabalhava na História Viva, pelo menos 60\%, 70\% do meu tempo eu estava no computador mexendo em texto; hoje, o que eu faço na prática não tem nada a ver com mexer no texto. Hoje, o que eu faço é pesquisar, identificar e avaliar projetos de pesquisa que eu acho que podem render bons livros, então é outra coisa completamente diferente. Na verdade, é como se eu fosse uma espécie de headhunter de autores. O meu trabalho é justamente entrar em contato, conversar com essas pessoas e buscar novos livros que eu acho que vão ser legais para o portfólio da editora. Eu costumo brincar que se me perguntarem o que eu faço hoje eu respondo "eu escrevo e-mail, eu mando emails", é basicamente isso. Meu trabalho hoje é escrever e-mails, participar de congressos científicos, me reunir com autores, é uma coisa muito mais abstrata do que quando eu trabalhava na História Viva.

Revista Epígrafe: Só para esclarecer sobre seu trabalho na Springer. Você tem diretrizes que vêm da editora, as diretrizes é você que cria para sua área, como é? Por exemplo, hoje os estudos de gênero frequentemente feitos na academia. Você tenta ver quais são as tendências internacionais, de onde vêm essas diretrizes?

Bruno Fiuza: Aqui no Brasil, a publicação científica é muito pouco profissionalizada. Essa é a parte ruim. A parte boa é que é uma atividade muito pouco mercantilizada também. Então a gente está acostumado, aqui no Brasil, a processos editoriais extremamente artesanais. Quando você fala de publicação científica internacional, aí é outro mundo, a gente está falando de business mesmo, de negócios que movimentam bilhões de dólares. Então existe uma dimensão mercadológica no trabalho que eu faço hoje que dificilmente existe no trabalho de alguém que trabalha com publica- 


\section{entrevista}

Bruno Fiuza

ção científica no Brasil, porque eu vou trabalhar na dimensão da análise crítica do conteúdo, isso é uma coisa; análise mercadológica daquilo, isso é outra coisa. E também tem uma terceira dimensão que são as diferenças entre as demandas do público em diferentes ambientes, em diferentes tradições culturais, porque aqui no Brasil, na América Latina em geral, a nossa tradição nas Ciências Humanas e Sociais, é a tradição francesa, que é muito diferente da tradição anglo-saxã; quando a gente fala de publicação internacional hoje, a gente está falando da anglo-saxã. Então, a própria forma de enquadrar os conhecimentos dos campos é diferente. Por exemplo, eu fui contratado, o título do cargo quando eu fui contratado era "editor de Ciências Sociais". Eu imaginava que eu não ia trabalhar com História porque a Springernão publica História, imaginava que eu fosse trabalhar com Sociologia, Antropologia, Ciência Política, essas coisas. Eu até faço isso marginalmente, mas assim, o grosso que eu faço é trabalhar com Psicologia e Saúde Pública. E quando você olha para trás, a tradição de ciência do mundo anglo-saxão é muito mais positivista, quantitativista, etc., então, muitas vezes é difícil enquadrar a tradição daqui nesse molde.

Aqui, os critérios têm muito a ver com o que o público quer. Então, muitas vezes, eu trabalho numa situação que ela é um pouco sui generis, porque o que eu publico em inglês, o grosso do que eu publico não vai ser consumido aqui. O que eu faço é muito mais levar um conteúdo vindo daqui da América Latina para um público internacional, do que publicar para um público daqui. O critério passa pela forma como o catálogo da editora construiu a abordagem de um determinado campo de conhecimento. Por exemplo, na área que eu mais trabalho, que é a psicologia: aqui no Brasil a psicanálise é muito forte, mas a Springer não publica psicanálise, porque na perspectiva da editora a psicanálise não tem uma metodologia quantitativa, etc. Então, eu vou publicar livros de psicologia clínica, qual o critério? Bom, um critério é "não entra psicanálise", o que é super estranho do ponto de vista brasileiro, mas o que acontece 


\section{entrevista}

Entre ler, traduzir e comunicar

é que as pessoas que vão ler esse texto são pessoas que julgam que a psicanálise não é uma forma de psicologia científica. Então, eu diria que um dos principais critérios é entender o que buscam as comunidades com as quais eu estou trabalhando.

Revista Epígrafe: As pessoas também submetem trabalhos para vocês ou é só você que faz esse processo de procurar?

Bruno Fiuza: Na verdade, é um processo duplo: tanto eu vou atrás de autores quanto eu recebo propostas de livro. Os meus colegas que trabalham fora do Brasil recebem muito mais proposta do que a gente aqui, porque as pessoas já estão acostumadas a trabalhar com uma editora assim. Aqui, principalmente no lado da Ciências Humanas e Sociais, a publicação em inglês não é uma coisa tão difundida, então, muitas vezes, eu preciso ir atrás das pessoas porque muita gente não sabe que existe a possibilidade.

Mas aí eu acho que tem uma questão mais prática que é importante falar: o meu método de trabalho é muito parecido com a forma de trabalho dos periódicos. Não sou eu que avalio uma proposta de livro. Eu faço uma avaliação inicial de uma proposta, mas eu mando essa proposta para um especialista na área para ele me dizer se aquela proposta é boa ou não, porque eu não tenho como avaliar um trabalho de neurocientistas, por exemplo. Eu trabalho com aquilo que a gente chama de revisor, é um processo de revisão por pares. Isso também é muito diferente do que eu fazia na História Viva, porque ali quem avaliava era eu, porque eu sou historiador.

Revista Epígrafe: Uma coisa que a gente tem discutido aqui na graduação: como a gente extrapola a universidade, como a gente sai desse meio acadêmico? Quais são os caminhos possíveis dentro das publicações, seja em revistas mais populares ou 


\section{entrevista}

Bruno Fiuza

com livros? Porque nós temos historiadores que fazem divulgação, como a Lilia Schwarcz, mas também temos jornalistas que fazem esse papel...

Bruno Fiuza: Essa é uma questão com a qual eu convivia muito na época da História Viva. Eu acho que nós historiadores sofremos com uma armadilha quando a gente fala de mercado editorial, por conta da natureza do conhecimento com o qual a gente trabalha. É o seguinte: o historiador lida com um conhecimento que, apesar de ter os seus jargões, apesar de ter os seus códigos, é muito mais acessível para um leigo do que um cientista das Ciências Naturais, e eu acho que isso cria uma enorme confusão para gente. Não passa pela cabeça de um físico que ele vai escrever para o grande público. Para você ler um artigo científico de Física, você precisa ter uma quantidade de conhecimentos que um leigo não tem. Então, nas Ciências Naturais é muito evidente a diferença da publicação científica e a divulgação científica, eles têm muita clareza disso. Eu acho que no nosso campo isso é confuso e isso deveria ser mais claro.

Divulgação científica e publicação científica stricto sensu são coisas diferentes. A publicação acadêmica, a comunicação acadêmica, ela é uma comunicação entre pares, eu não vou publicar um artigo na Revista de História esperando que minha avó vá ler, porque ela não vai, não é essa a função. Quando eu publico um artigo na Revista de História, eu estou comunicando com os meus pares, então a linguagem é sim codificada, a estrutura é codificada, é cheia de jargões, e não tem problema. Porque aqui eu estou comunicando um conceito altamente especializado para um público altamente especializado e que vai ser capaz de me entender. A comunicação científica é assim, não tem nada de errado nisso. Não deve se esperar que o conhecimento produzido na academia esteja à disposição do público automaticamente, não é essa a função da academia. A função da academia é produzir conhecimento de acordo com suas normas validadas, etc. 


\section{entrevista}

Entre ler, traduzir e comunicar

Agora, existe a divulgação científica, que é um trabalho em si. É uma pessoa que vai ter conhecimento necessário para entender uma publicação especializada e vai produzir um texto para um público leigo. Isso é divulgação científica. Quando eu trabalhava na História Viva existiam muitos mal entendidos entre historiadores e jornalistas. Jornalista achando que podia ser historiador, historiador achando que podia ser jornalista. São coisas diferentes. Uma coisa é fazer divulgação. E a divulgação em si é uma coisa que exige habilidades, competências e existem grandes divulgadores. Por exemplo, na minha opinião, Laurentino Gomes é um grande divulgador, mas ele não é historiador. Ele é um leitor de livros que pega aquele conhecimento e joga para um grande público. Agora, para existir um Laurentino, precisa existir um István, que vai passar a vida num arquivo, vai investigar um determinado assunto com uma determinada metodologia e ele vai publicar um livro que três pessoas vão ler, porque são pessoas da área dele.

Você citou o caso da Lilia, que é um caso raro de uma pessoa que é, ao mesmo tempo, uma grande pesquisadora e uma grande divulgadora. É a mesma coisa a Mary Del Priore. Para mim, o grande paradigma é o [Eric] Hobsbawm: é um grande pesquisador e um grande divulgador. A Era dos Extremos não é um livro de pesquisa, é um livro de síntese, a gente precisa de pessoas que façam isso, mas para o Hobsbawm poder escrever esse livro, alguém precisou ficar fazendo gráfico de curva do aumento do PIB do país... Isso não é o divulgador que vai ficar fazendo, isso exige um conhecimento especializado, metodologias especializadas. Na minha opinião, como a gente vai resolver essa equação de "produzir conhecimento de boa qualidade" e "permitir que esse conhecimento chegue para sociedade" é ter clareza dos papéis, não exigir do pesquisador que ele seja, necessariamente, um bom divulgador, e nem achar que um bom divulgador é um bom pesquisador. 


\section{entrevista}

Bruno Fiuza

Entre o fim dos anos 1990 e a primeira década dos anos 2000, a História estava na moda. Acho que teve divulgadores que contribuíram com isso, como o Laurentino, por exemplo. Tem um jornalista chamado Lira Neto, que eu acho que é um ótimo divulgador também. Você tem o Eduardo [Bueno], que tem problemas, mas enfim, eu acho que ele foi o precursor dessa onda de divulgadores. E você têm canalhas, como o Leandro Narloch. Eu não tenho nenhum problema em falar que o Leandro Narloch é um canalha e se ele aparecer na minha frente eu falo isso na cara dele sem problema nenhum. Por quê? Porque é um mau caráter, é um cara que usa uma pesquisa séria para fazer propaganda ideológica. Então, na minha ideia, o Leandro Narloch é um mau divulgador. É uma total irresponsabilidade o que ele faz, o que ele faz com pesquisas sérias, porque se você olha a bibliografia do Leandro Narloch, ele cita pesquisas seríssimas. Por exemplo, o capítulo dele de Zumbi tem muita coisa da pesquisa do Flávio dos Santos Gomes, que é um dos maiores pesquisadores de escravidão no Brasil, mas ele pinça partes que ele quer para construir o discurso ideológico. Eu tive a felicidade de trabalhar com o Laurentino na época que eu era editor da História Viva, na época que ele lançou o segundo livro dele, o 1822, e ele produziu versões condensadas de capítulos do livro para uma versão especial da revista. O que ele fez em 1822, por exemplo, foi trabalhar com historiadores, ele trabalhou com o Alberto [da Costa e] Silva. Esse é o papel do divulgador.

E tem um outro ponto, relacionado com a nossa tradição francesa. Ainda que a França tenha uma tradição de divulgação, essa divulgação já é de um nível intelectual que a maioria das pessoas do Brasil não tem. Eu falo isso porque a História Viva era, em parte, a edição brasileira de uma revista francesa de divulgação, só que eu acho que é um nível que não condiz com a nossa realidade. A tradição britânica, por exemplo, tem uma tradição de divulgadores enorme. Na BBC, os historiadores que vão fazer um programa, é um pesquisador que se torna um divulgador, mas ele tem um 


\section{entrevista}

Entre ler, traduzir e comunicar

treinamento próprio para ser divulgador. Não se espera que o artigo que ele vá publicar na revista [acadêmica] vá ser para o público em geral. Não, não é, e eu acho que a gente precisa ter essa clareza.

Revista Epígrafe: Aproveitando essa última questão, como você vê o campo editorial brasileiro, pensando um pouco os livros de História?

Bruno Fiuza: O mercado editorial brasileiro está numa crise profunda. A experiência que eu tive na História Viva, eu não sei se é uma experiência que eu poderia ter hoje, porque as revistas estão numa crise terrível, as editoras de livro estão numa crise terrível. Eu acho, em primeiro lugar, que as editoras de livro no Brasil precisam de uma estrutura mais profissionalizada. A maioria das editoras acadêmicas brasileiras têm estruturas muito pouco profissionalizadas -- claro, as universitárias, a Edusp, a Unesp, Unicamp têm uma estrutura linda. Mas a Edusp tem que publicar livros e vender mil cópias para a Saraiva? Não. A Edusp tem que publicar livros de interesse da comunidade acadêmica. Aí a Companhia das Letras, que é um caso muito sui generis. um livro de história pode vender na livraria, até quem não é historiador vai comprar, um livro do [João] José Reis, por exemplo. Os livros que eu publico pela Springer, eu não espero que um leigo consiga ler, porque ele não vai conseguir, é outra coisa. Essa é a armadilha das Ciências Humanas. Os livros de História ficam nessa posição ambígua, tem livros de História que podem ser lidos pelo grande público e existem livros de História que talvez não, por exemplo, um livro que faz uma grande discussão metodológica não vai vender na livraria, mas a gente precisa desses livros.

Eu acho que para essa questão da produção de conhecimento bem feita que atinge um público amplo, para mim a resposta curta para isso é ter clareza do que é pesquisa, do que é divulgação, e fazer os dois bem feito. Por exemplo, o Coggiola é 


\section{entrevista|}

Bruno Fiuza

um ótimo divulgador. Se você der um texto do Coggiola para uma pessoa na rua, ela lê. Agora, se você pega, por exemplo, um livro de Teoria da História do Jorge Grespan, não é para qualquer um ler.

Revista Epígrafe: Para encerrar, então, quais sugestões você daria para um estudante que está interessado em entrar na área editorial?

Bruno Fiuza: A primeira sugestão é ter clareza com que tipo de publicação você quer trabalhar. Por exemplo, você quer trabalhar com livro didático? Isso é um campo, um campo bastante grande, etc. Você quer trabalhar com publicação científica? Eu acho que as revistas acadêmicas brasileiras precisam de muita profissionalização. Em ambientes onde as revistas são mais profissionalizadas é uma boa opção, mas aqui no Brasil é muito pouco, em geral as revistas são feitas de um modo muito artesanal. Você quer trabalhar com divulgação científica? Então vai ser outra coisa diferente. Eu acho muito importante você ter clareza do tipo de publicação que você quer trabaIhar. Acho que um outro conselho que eu dou é conhecer o mercado editorial, conhecer as editoras que trabalham na área que você quer trabalhar, saber o que que elas publicam, como elas publicam, para quem elas publicam. Mas, assim, eu estou falando como se essas coisas fossem sempre muito planejadas e o negócio é que elas não são. Acho que é importante também ter em mente que muitas vezes as coisas vão aparecer de onde você não espera e aí cito meu exemplo mesmo: eu fiz o meu mestrado porque meu objetivo era seguir carreira acadêmica; no meio do caminho apareceu essa oportunidade da Springer, eu nunca imaginei que eu ia trabalhar com isso. Então, às vezes a pessoa acha que vai fazer carreira como um editor de livros didáticos, calma! Ao mesmo tempo que é importante conhecer e saber o que você quer, é importante também ter em mente que ter essa flexibilidade de saber que nem sem- 


\section{entrevista}

Entre ler, traduzir e comunicar

pre o plano que você fez vai dar certo, às vezes você mira em um lugar e acerta no outro. É importante ter uma visão realista também, saber que o mercado editorial brasileiro, hoje, é um mercado em crise, então é bom moderar as expectativas. Uma coisa que eu acho legal também é a pessoa se informar sobre a atividade editorial em si, porque o mercado editorial é um mercado que está mudando muito. A digitalização, os novos formatos, tudo isso está mudando.

Uma coisa que eu acho que vale para tudo na vida: mais importante que um conhecimento específico, é ter a habilidade de aprender, é aprender a aprender. É saber que, por melhor que seja o seu plano, muitas vezes ele não vai funcionar, e no meio do caminho você vai ter que aprender coisas que ninguém te ensinou. Essa flexibilidade, ela é realmente muito importante. Sendo totalmente honesto com vocês, eu nunca aprendi a ser editor, tudo que eu fiz até hoje na vida, eu aprendi trabalhando, isso não quer dizer que não existam recursos para a pessoa se formar. O historiador vai se tornar editor, e eu acho que o historiador ele tem uma formação muito legal para ser editor, mas ele não vai aprender na faculdade as coisas que ele vai ter que fazer no dia-a-dia. Tem alguns campos específicos no mercado editorial onde existe um esforço do próprio campo em fornecer essa formação. No campo de editoração de periódicos científicos existem associações, existem cursos; se a pessoa quer trabalhar com livro didático, por exemplo, pode ter umas optativas aqui na USP de produção de material didático; de repente, a pessoa faz uma optativa na ECA [Escola de Comunicações e Artes da USP] para ter uma formação bacana. Acho que trabalhar no mercado editorial é uma possibilidade desse leque do historiador. Então, como não existe um currículo pensado para isso, provavelmente a pessoa vai ter que criar o seu próprio currículo, digamos assim, e aí é legal conversar com quem trabalha na área para conhecer. Eu acho que muitas pessoas que trabalham na área tem a maior disponibilidade para conversar. Eu acho que é isso, que talvez a primeira coisa seja 


\section{entrevista}

Bruno Fiuza

colocar no mapa que essa é uma possibilidade, aí buscar os caminhos. Mas, como vocês podem ver pela minha trajetória, eu não sou uma boa pessoa para falar de planejamento de carreira, no meu caso não foi assim que aconteceu. 